\title{
Decreased G-Protein-Mediated Regulation and Shift in Calcium Channel Types with Age in Hippocampal Cultures
}

\author{
Eric M. Blalock, Nada M. Porter, and Philip W. Landfield \\ Department of Pharmacology, College of Medicine, University of Kentucky, Lexington, Kentucky 40536
}

The membrane density of L-type voltage-sensitive $\mathrm{Ca}^{2+}$ channels (L-VSCCs) of rat hippocampal neurons increases over age [days in vitro (DIV)] in long-term primary cultures, apparently contributing both to spontaneous cell death and to enhanced excitotoxic vulnerability. Similar increases in L-VSCCs occur during brain aging in vivo in rat and rabbit hippocampal neurons. However, unraveling both the molecular basis and the functional implications of these age changes in VSCC density will require determining whether the other types of highthreshold VSCCs (e.g., N, P/Q, and R) also exhibit altered density and/or changes in regulation, for example, by the important G-protein-coupled, membrane-delimited inhibitory pathway. These possibilities were tested here in long-term hippocampal cultures.

Pharmacologically defined whole-cell currents were corrected for cell size differences over age by normalization with whole-cell capacitance. The $\mathrm{Ca}^{2+}$ channel current density (picoamperes per picofarad), mediated by each $\mathrm{Ca}^{2+}$ channel type studied here ( $L, N$, and a combined $P / Q+R$ component), increased through 7 DIV. Thereafter, however, only L-type current density continued to increase, at least through 21 DIV. Concurrently, pertussis toxin-sensitive G-protein-coupled inhibition of non-L-type $\mathrm{Ca}^{2+}$ channel current induced by the $\mathrm{GABA}_{\mathrm{B}}$ receptor agonist baclofen or by guanosine $5^{\prime}-3-\mathrm{O}-$ (thio)triphosphate declined dramatically with age in culture. Thus, the present studies identify selective and novel parallel mechanisms for the time-dependent alteration of $\mathrm{Ca}^{2+}$ influx, which could importantly influence function and vulnerability during development and/or aging.

Key words: hippocampal neurons; aging; cell culture; calcium channel currents; L-type channels; N-type channels; baclofen; G-protein-mediated inhibition
A number of studies of neurons during the first days or weeks of age in vitro or in vivo have found that age-dependent changes in voltage-sensitive $\mathrm{Ca}^{2+}$ channels (VSCCs) are closely associated with the onset of several critical developmental functions. These functions include cellular differentiation (Spitzer et al., 1994), neurite outgrowth (Mattson and Kater, 1987; Rusanescu et al., 1995; Schmid and Guenther, 1999), synaptogenesis (Basarsky et al., 1994; Scholz and Miller, 1995), electrophysiological maturity (Groul et al., 1992), and patterns of neuronal intrinsic activity (Turrigiano et al., 1994, 1995).

In addition to the $\mathrm{Ca}^{2+}$ dependence of multiple developmental functions, however, neuronal excitotoxicity and other forms of cell death are strongly $\mathrm{Ca}^{2+}$-dependent (Olney, 1986; Choi, 1988; Abele et al., 1990; Dubinsky and Rothman, 1991; Tymianski et al., 1993; Lipton, 1994; Ankarcrona et al., 1995). Furthermore, it has become increasingly evident that the susceptibility of primary cultured neurons to $\mathrm{Ca}^{2+}$-mediated excitotoxic insult rises dramatically with age in culture, particularly between 1 and 3 weeks in culture (Choi, 1987, 1988; Frandsen and Schousboe, 1990; Regan and Choi, 1991; McDonald et al., 1997; Adamec et al., 1998).

However, in contrast to the extensive studies of VSCCs and developmental functions in younger neurons, little is known

\footnotetext{
Received May 14, 1999; revised July 19, 1999; accepted July 20, 1999.

This work was supported in part by grants National Institute on Aging Grants AG04542 and AG10836. We thank Elsie Barr, Jann Geddes, and Veronique Thibault for important technical assistance and Kelley Secrest for excellent assistance with this manuscript.

Correspondence should be addressed to Dr. Eric M. Blalock, Department of Pharmacology, MS-310 UKMC, University of Kentucky, Lexington, KY 405360298.

Copyright (C) 1999 Society for Neuroscience $\quad 0270-6474 / 99 / 198674-11 \$ 05.00 / 0$
}

about how age-dependent alterations in VSCCs may contribute to the enhanced vulnerability of more mature neurons. Although excitotoxicity is often attributed to $\mathrm{Ca}^{2+}$ influx through NMDA receptors (see above), and NMDA currents and binding proteins change with age in culture (Mattson et al., 1991; Ujihara and Albuquerque, 1992; Xia et al., 1995), there is also substantial evidence that VSCCs play some role in glutamate excitotoxicity (Weiss et al., 1990; Lipton, 1994; Geddes et al., 1997; Kimura et al., 1998; Roy et al., 1998). Moreover, during normal glutamatergic synaptic transmission, the resulting postsynaptic depolarization also strongly activates $\mathrm{Ca}^{2+}$ influx through VSCCs (Brown and Jaffe, 1994; Magee and Johnston, 1995; Bollmann et al., 1998).

Thus, it seems possible that VSCCs could be involved in enhanced excitotoxic vulnerability with age in culture, which is in part supported by our recent finding that L-type VSCCs (LVSCCs) in hippocampal neurons exhibit a substantial agedependent increase over $28 \mathrm{~d}$ in vitro (DIV). Over the same period spontaneous cell death can be blocked by nimodipine, an L-VSCC antagonist (Porter et al., 1997), and L-type VSCCs contribute increasingly to both glutamate-induced $\mathrm{Ca}^{2+}$ transients and excitotoxicity (Geddes et al., 1997; Thibault et al., 1997).

Altered VSCCs could be relevant to changing function or vulnerability during normal brain aging as well. Although various aspects of altered $\mathrm{Ca}^{2+}$ homeostasis appear to play important roles in brain aging and/or dementia (for review, see Disterhoft et al., 1994; Khatchaturian, 1994; Thibault et al., 1998; Verkhratsky and Toescu, 1998), increased L-VSCC currents, potentials, or single-channel densities are seen in hippocampal neurons of aging rats and rabbits (Landfield et al., 1989; Moyer et al., 1992; Dis- 
terhoft et al., 1994; Campbell et al., 1996). However, it remains unknown whether age changes in VSCC density either in vivo or in vitro are selective for the L-type VSCC or instead also occur in other types of high-threshold VSCCs (N, P/Q, and R types).

Apart from changes in channel density, $\mathrm{Ca}^{2+}$ influx through $\mathrm{N}$ and P/Q-type VSCCs is also strongly and negatively regulated by a membrane-delimited, G-protein-coupled inhibitory pathway activated by several neurotransmitters (Holz et al., 1986; Hescheler et al., 1987; Bean, 1989; Cox and Dunlap, 1992; Delcour and Tsien, 1993; Hille, 1994; Dolphin, 1995; Currie and Fox, 1997; Zamponi and Snutch, 1998). Because synaptic transmission is consistently impaired with aging (Barnes and McNaughton, 1980; Landfield et al., 1986; Rose et al., 1986; Bickford-Wimer et al., 1988; Hoffer et al., 1988; Barnes, 1994; Geinisman et al., 1994), as is neurotransmitter-activated G-protein coupling to nonmembrane-delimited second messenger systems (Wang et al., 1992; Roth et al., 1995; Cowburn et al., 1996), it seems possible that non-L-VSCC regulation by neurotransmitters could also be affected by age. However, the membrane-delimited pathway has not yet been studied extensively in relation to age either in vitro or in vivo.

Thus it clearly seems essential for a comprehensive view of the molecular mechanisms and functional implications of agedependent alterations in VSCC density to test the hypothesis that changes in the density and/or regulation of non-L-VSCCs occur in parallel to the age-dependent density changes seen in L-type VSCCs. The present studies examined this hypothesis in longterm primary cultures.

\section{MATERIALS AND METHODS}

Cell culture. Primary cultures of hippocampal cells were established using a modification of the procedure of Banker and Cowan (1977). The day before plating, plastic culture dishes containing Thermanox plastic coverslips (Nunc, Naperville, IL) were treated with poly-L-lysine $(100 \mu \mathrm{g} /$ $\mathrm{ml}$ ). On the day of plating, pregnant female Sprague Dawley rats were killed using $\mathrm{CO}_{2}$ and cervical dislocation, and fetal (embryonic day 18) rats were obtained by cesarean section, in accordance with protocols approved by the institutional animal care committee. The embryonic hippocampi were dissected and incubated for $10 \mathrm{~min}$ in an enzymatic solution $(0.25 \%$ trypsin and $1 \mathrm{~mm}$ EDTA in HBSS), washed three times in minimal essential medium (MEM), and triturated to dissociate cells. One milliliter of the resulting cell suspension (diluted to $3-5 \times 10^{5}$ cells $/ \mathrm{ml}$ ) and $1 \mathrm{ml}$ of supplemented MEM (SMEM; MEM with $10 \%$ fetal bovine serum and $10 \%$ horse serum) then were added to poly-L-lysinecoated dishes and coverslips. Cultures were placed in an incubator $(5 \%$ $\mathrm{CO}_{2}, 36^{\circ} \mathrm{C}$ ) overnight, and the following day half the culture medium was replaced with $1 \mathrm{ml}$ of SMEM containing $10 \%$ horse serum but no fetal bovine serum $(\mathrm{SMEM} / \mathrm{H})$. To prevent glial proliferation, at 5 DIV $1 \mathrm{ml}$ of culture media was replaced with $1 \mathrm{ml}$ of SMEM/H supplemented with $15 \mu \mathrm{g} / \mathrm{ml}$ 5-flouro-2'-deoxyuridine (antimitotic) and $35 \mu \mathrm{g} / \mathrm{ml}$ uridine (to support RNA synthesis).

Age comparisons were performed in sister cultures allowed to age for different durations up to 21 DIV. To obtain a sufficient number of cells per age point and to ensure that results were not specific for a given culture, the experiments were repeated in three different culture platings. No significant differences in average current were found among the three different culture platings at any age point (two-way ANOVA, $p<0.6$ for plating; $p<0.001$ for age of culture), and the age-matched data from the different platings were, therefore, pooled for further analysis (total cells $=76 ; 3$ DIV,$n=7 ; 7$ DIV, $n=24 ; 14$ DIV, $n=23 ; 21$ DIV, $n=21)$.

Electrophysiological recording. A modified version of the "coverslip" method of Randall and Tsien (1995) was used for recording procedures. A small $(\sim 4 \times 4 \mathrm{~mm})$ piece of the plastic coverslip was cut out using sterile procedures, transferred to a bath perfusion chamber (Warner Instruments, Hamden, CT), and discarded after recording. The remaining coverslip was returned to the incubator. This method allowed us to record multiple cells from a single culture dish each day. The whole-cell bath solution contained (in mM): $111 \mathrm{NaCl}, 5 \mathrm{BaCl}_{2}, 5 \mathrm{CsCl}, 2 \mathrm{MgCl}_{2}, 10$ glucose, 10 HEPES, 20 TEA-Cl, and 0.001 tetrodotoxin (TTX). The $\mathrm{pH}$ was adjusted to 7.35 with $\mathrm{NaOH}$; the osmolarity was adjusted to 330 mOsm with sucrose. The pipette solution contained (in mM): 145 methanesulfonic acid, 10 HEPES, $2.34 \mathrm{MgCl}_{2}, 10$ BAPTA, $5 \mathrm{MgATP}, 13$ TEA-Cl, and 0.1 leupeptin. The $\mathrm{pH}$ was adjusted to 7.35 with $\mathrm{CsOH}$, and the osmolarity was adjusted to 320 mOsm with distilled $\mathrm{H}_{2} \mathrm{O}$. Pipette solution was aliquoted and frozen $\left(-20^{\circ} \mathrm{C}\right)$ for later use.

All recordings were performed at room temperature $\left(21-22^{\circ} \mathrm{C}\right)$. Electrodes were pulled from Fisher Scientific (Houston, TX) microhematocrit nonheparinized glass capillaries (catalog \#02-668-68) with a Flaming-Brown horizontal puller (Sutter Instruments, Novato, CA). Electrodes were coated with polystyrene Q-dope (GC Electronics, Rockford, IL) and had resistances averaging $\sim 2.2 \mathrm{M} \Omega$. The junction potential was nulled with the electrode in the bath, and the whole-cell patch-clamp recording configuration was established according to standard methods (Hamill et al., 1981). Cells were voltage-clamped at $-70 \mathrm{mV}$ with an Axopatch 200 patch-clamp amplifier (Axon Instruments, Foster City, CA). After allowing 5-10 min for whole-cell current to stabilize, command voltage steps were administered, and the resulting current records were digitized and stored using pClamp (6.03) software.

Experimental protocols. In a study of whole-cell current change with age, cell size is a critical control issue. Therefore, whole-cell current amplitude was normalized throughout by dividing by whole-cell capacitance to yield current density (picoamperes per picofarad). Cell capacitance and series resistance were measured at the start of each recording in each cell. Passive membrane current was evoked with small, hyperpolarizing $(-5 \mathrm{mV})$ voltage steps from a holding potential of $-70 \mathrm{mV}$, and the current records were low-pass-filtered at $10 \mathrm{kHz}$ and digitized at 91 $\mathrm{kHz}$ to allow accurate resolution of the decay of the capacitive current. It is well recognized that whole-cell capacitance is directly proportional to cell size (membrane surface area) (Cahalan and Neher, 1992). However, because dendritically ramified hippocampal neurons are not isopotential and can often have decay time constants that are best fit by multiple exponentials (Johnston and Brown, 1983; Spruston et al., 1993; Carnevale et al., 1997), we used the method of integrating the area under the curve of the capacitive transient to estimate whole-cell capacitance (Ulrich et al., 1994; Kang et al., 1996; Mathes, 1998). Series resistance was estimated from the instantaneous peak onset current. Active current records were low-pass-filtered at $2 \mathrm{kHz}$, digitized at $3.64 \mathrm{kHz}$, and leak subtracted using a $\mathrm{P} /-5$ protocol.

The same current-voltage $(I-V)$ protocols were performed on each neuron. Cells were held at $70 \mathrm{mV}$, and successively less negative command potentials (150 msec duration) were applied in $10 \mathrm{mV}$ increments every $45 \mathrm{sec}$. After determining the voltage at which maximal current was generated, that potential $(+10$ to $+20 \mathrm{mV})$ was applied every $30 \mathrm{sec}$ during the application of pharmacological agents. A second $I-V$ curve was then recorded to determine whether a treatment had shifted the voltage dependence. Cells with $<500 \mathrm{M} \Omega$ whole-cell resistance were discarded. Series resistances (SRs) for recorded cells averaged $\sim 7.5 \mathrm{M} \Omega$, which resulted in only minor voltage distortions. Series resistance was not compensated, because our own observations, as well as those of others (Randall and Tsien, 1995), have consistently indicated that at these current amplitudes there is no apparent difference in whole-cell $\mathrm{Ca}^{2+}$ channel current amplitude or kinetics before or after SR compensation.

To help distinguish between the more rapidly inactivating and more slowly inactivating current types, three different components of the whole-cell current were measured during command voltage steps: (1) average step current (the integral of the step current divided by the step duration); (2) peak current (initial maximal inward current during the step); and (3) late current (10 msec before the end of the step). For simplicity, average step current is not illustrated throughout, although it should be noted that its amplitudes and patterns were generally intermediate between late and peak current. As noted above, each component was normalized for differences in cell size within and across ages by transformation to current density (picoamperes per picofarad) (dividing each current measure by the whole-cell capacitance for that cell).

Hippocampal neurons in vivo and in vitro exhibit a long-lasting tail-like, or repolarization, $\mathrm{Ca}^{2+}$ (or $\mathrm{Ba}^{2+}$ ) channel current (Campbell et al., 1996; Porter et al., 1997). This repolarization current may be attributable to openings of VSCCs seen at the single-channel level on repolarization (Fisher et al., 1990; Slesinger and Lansman, 1991; Forti and Pietrobon, 1993; Thibault et al., 1993; Kavalali and Plummer, 1994; Thibault and Landfield, 1996), because these openings can be extremely frequent at physiological concentrations of divalent charge carrier (Thibault et al., 
A

Figure 1. $\mathrm{Ca}^{2+}$ channel current increase over age in culture. $A$, Whole-cell current averaged for each age group $(n=7,24,23$, and 21 for $3,7,14$, and 21 DIV, respectively) revealed a dramatic increase in peak current amplitude with age in culture. $B$, $I-V$ experiments showed that maximum inward current was generated by similar voltage steps in all ages tested. $C$, Capacitancenormalized current revealed a large increase in density between 3 and 7 DIV with a trend toward increasing current density at later time points.
B

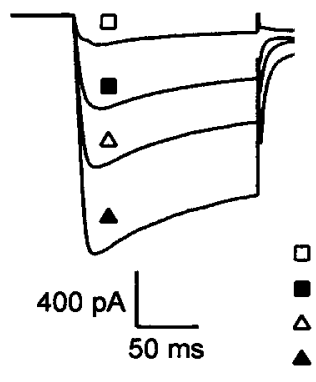

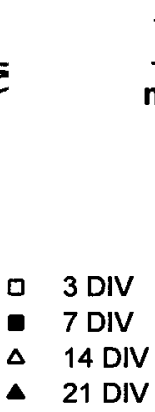

21 DIV

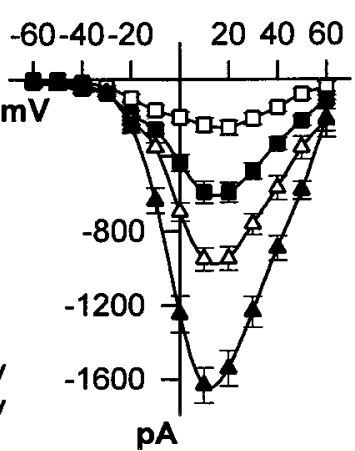

C

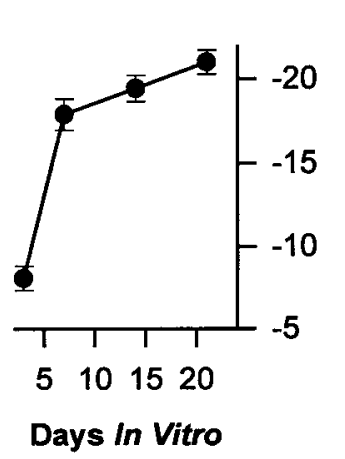

1993). However, another possibility is that this current could arise from unclamped $\mathrm{Ca}^{2+}$ channels in small basilar dendrites (Johnston and Brown, 1983; Armstrong and Gilly, 1992; Spruston et al., 1993; Carnevale et al., 1997). Nevertheless, because of the long duration of the tails, such sites would have to be extremely distant electrotonically (i.e., slow currents are less affected by space-clamp problems). We have also ruled out the possibility that the tail currents arise from poor space clamp of the large apical dendritic tree. Experiments in which the major apical dendrites of cultured neurons were severed or patch-clamped simultaneously with the soma did not change the shape or proportional amplitude of tail current. Furthermore, current-clamp recordings from the apical dendrites of somatically voltage-clamped neurons showed that, during steps to command potentials the apical dendrite was very well clamped (Thibault et al., 1995), as might be anticipated from its large diameter and relative electrotonic proximity (Johnston and Brown, 1983; Spruston et al., 1993; Carnevale et al., 1997). Finally, the long tail can be inactivated separately from the main command step current without altering the step current amplitude or shape (Mazzanti and Landfield, 1994). However, because of the ambiguity of its origin, tail current was not analyzed or illustrated in the present study.

Drug application. Drugs were applied using "weeper" perfusion pipettes $(5-10 \mu \mathrm{m}$ tip glass pipettes filled with appropriate drug concentrations and positioned two somal diameters from the cell) or by bath perfusion, as described in Results. Saturating concentrations of nimodipine $(10 \mu \mathrm{M}$ in $0.1 \% \mathrm{EtOH})$ and $\omega$-conotoxin GVIA ( $\omega$-CTX; $1 \mu \mathrm{M}$ in $0.1 \mathrm{mg} / \mathrm{ml}$ cytochrome $c$ ) were used to selectively inhibit L- and N-type currents, respectively. To control for vehicle effects both EtOH and cytochrome $c$ were present in all solutions. The $\mathrm{Na}^{+}$channel blocker TTX $(1 \mu \mathrm{M})$ was included in the weeper solution but not the bath recording solution to detect obstructed perfusion pipettes. Clogged weepers were identified by the emergence of a fast $\mathrm{Na}^{+}$spike current in the record.

Data analysis. SigmaStat (version 2.0) software was used for statistical analysis and specific tests are described in Results. Nonlinear fits were carried out using the TableCurve 2D (version 2.03) curve-fitting software. Data from nimodipine concentration-response experiments were fit by the following equation (Taylor and Insel, 1990):

$$
\text { response }=\frac{a}{\left(1+(x / b)^{c}\right)},
$$

where $a$ is $I_{\max }$ (the maximum amount of current inhibited), $b$ is $I C_{50}$, and $c$ is the slope of the response over its linear range. To determine whether fitted parameters differed significantly with treatment or age, they were compared using the $z$ test (Armitage and Berry, 1990) as follows:

$$
z=\frac{X-\mu}{\sqrt{\mathrm{SE}_{X}^{2}+\mathrm{SE}_{\mu}^{2}}},
$$

where $X$ and $\mu$ are the fitted parameters to be compared, $\mathrm{SE}_{X}$ is the $\mathrm{SE}$ for $X$, and $\mathrm{SE}_{\mu}$ is the standard error for $\mu$. If $z<2$, then the compared parameters were not considered significantly different.

Chemicals. Baclofen- $( \pm)$, nimodipine, and $\omega$-CTX were obtained from Research Biochemicals (Natick, MA). All other chemicals were obtained from Sigma (St. Louis, MO). Nimodipine was stored in opaque containers at $-20^{\circ} \mathrm{C}$ as a $10 \mathrm{~mm}$ stock solution in $100 \% \mathrm{EtOH}$. Baclofen was dissolved in distilled $\mathrm{H}_{2} \mathrm{O}$ for a stock solution of $100 \mathrm{~mm}$ and stored at $4^{\circ} \mathrm{C}$. $\omega$-CTx was prepared as a $1 \mathrm{~mm}$ stock in distilled $\mathrm{H}_{2} \mathrm{O}$ with an additional $100 \mathrm{mg} / \mathrm{ml}$ cytochrome $c$, aliquoted, and stored at $-20^{\circ} \mathrm{C}$.

\section{RESULTS}

\section{Increase in total current and total current density over age in culture}

A highly significant increase in total whole-cell current amplitude occurred with age in culture (Fig. $1 A ; p<0.001$, ANOVA). The $I-V$ experiments (Fig. $1 B$ ) indicated that voltage dependence and the step generating maximum inward current (usually +10 or $+20 \mathrm{mV}$ ) remained relatively stable with culture age. However, much of this age effect can be attributed to changes in cell size. Neurons and their processes grow substantially over time in culture (Yang et al., 1993; Porter et al., 1997), which, if channel density remains constant, increases whole-cell current amplitude. Neuronal growth with age was also seen in the present studies, as indicated by a significant age-dependent increase in total cell capacitance in these cultures (data not shown; $p<0.01$, ANOVA).

As noted, however, differences in cell size were corrected throughout by transforming the amplitudes to current density values (see Materials and Methods). The increase in total normalized current density with age was also highly significant $(p<$ 0.01 ) but showed a substantially different pattern from noncorrected current. Total current density increased rapidly between days 3 and 7 followed by a more slowly rising phase at later ages (Fig. 1C), similar to that seen by Porter et al. (1997).

\section{Pharmacological dissection of $\mathrm{Ca}^{2+}$ channel current}

The pharmacological dissection of specific types of $\mathrm{Ca}^{2+}$ channel current is well characterized and has to date identified at least five distinct types of voltage-sensitive $\mathrm{Ca}^{2+}$ channels, each of which has been linked to one or more unique $\alpha_{1}$ subunit genes. These types are commonly termed "L" (for long-lasting), "N" (for neuronal), "T" (for transient), "P/Q" (for Purkinje and $\mathrm{Q}$ for a related form), and "R" (for resistant) (Tsien et al., 1988; Llinás et al., 1989; Regan et al., 1991; Cox and Dunlap, 1992; Zhang et al., 1993; Bargas et al., 1994; Birnbaumer et al., 1994; Boland et al., 1994; Eliot and Johnston, 1994; Wu and Saggau, 1994; Catterall, 1995; Ishibashi et al., 1995; Lorenzon and Foehring, 1995; Randall and Tsien, 1995).

In the present studies, saturating concentrations of the selective $\mathrm{L}$ - and $\mathrm{N}$-type $\mathrm{Ca}^{2+}$ channel blockers $(10 \mu \mathrm{M}$ nimodipine and 1 $\mu \mathrm{M} \omega$-CTX, respectively) were used to define L-type and $\mathrm{N}$-type current. The remaining current ("residual") that was insensitive to either blocker was a composite presumably comprising $\mathrm{P} / \mathrm{Q}$ and $\mathrm{R}$ types (low-voltage-activated T-type current was largely ex- 


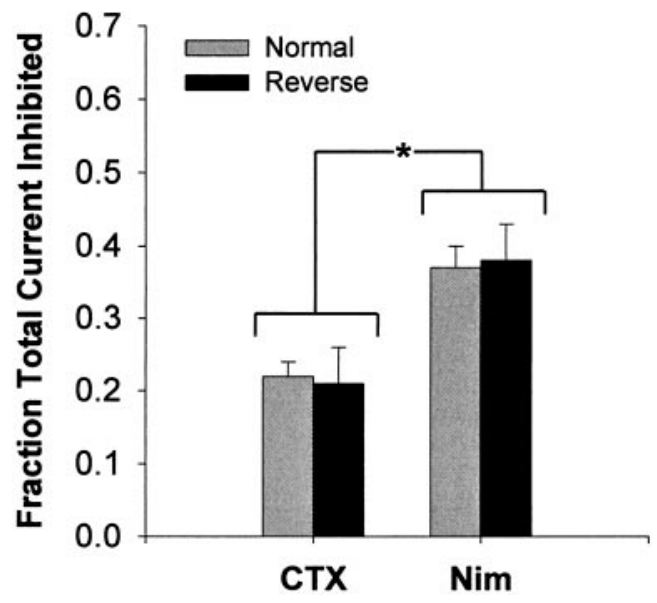

Figure 2. $\omega$-CTX and nimodipine inhibited nonoverlapping components of the current record. The fraction of mean $\mathrm{Ca}^{2+}$ channel current inhibited by nimodipine $(\mathrm{Nim} ; 10 \mu \mathrm{M})$ and $\omega$-CTX $($ CTX; $1 \mu \mathrm{M})$ was unchanged by switching the order of drug application from nimodipine first to $\omega$-CTX first. Two-Way ANOVA on repeated measures (RM), $p<0.01$ for drug type; $p>0.5$ for both presentation order and interaction.

cluded by our voltage protocols). A response was considered stable in the presence of a particular blocker when three successive depolarizations (interpulse interval, $30 \mathrm{sec}$ ) resulted in current traces that essentially overlapped. Whole-cell $\mathrm{Ca}^{2+}$ current was measured sequentially after exposure to vehicle alone, after exposure to vehicle plus nimodipine, and after exposure to vehicle and nimodipine plus $\omega$-CTX. Typically, $\omega$-CTX required 90 sec exposure to give stable inhibition, whereas nimodipine acted more rapidly $(<30 \mathrm{sec})$. Three waveforms were averaged at each measured time point and treated as a single current record for analysis.

\section{Selectivity of nimodipine and $\omega$-CTX}

Several studies have indicated that at high concentrations and in certain cell types dihydropyridines can inhibit some $\omega$-CTXsensitive current and, conversely, $\omega$-CTX can inhibit some dihydropyridine-sensitive current (Regan et al., 1991; Swandulla et al., 1991; Williams et al., 1992; Zhang et al., 1993; Diochet et al., 1995). To determine whether the blockers were selective and nonoverlapping in the present studies, drug presentation was reversed in separate groups of 21 DIV neurons. Nimodipine- and $\omega$-CTX-sensitive currents were converted to a fraction of the total current. Nimodipine- and $\omega$-CTX-sensitive current contributed $\sim 40$ and $\sim 20 \%$ of average step current, respectively, regardless of the presentation order of the blockers (Fig. 2). Therefore, the two $\mathrm{Ca}^{2+}$ channel blockers did not share a common site of inhibition in this preparation.

\section{Shifts in $\mathrm{Ca}^{2+}$ channel current composition with age in culture}

Total whole-cell current at maximally activating voltages increased more than eightfold between 3 and 21 DIV. Each of the uncorrected current-type components of the whole-cell current (e.g., L-, N-, and composite P/Q + R-type current) increased substantially and persistently throughout the age range examined (Fig. 3A). However, as described below, increases in current density were considerably more type- and age-selective (Fig. 3B).

\section{Peak current density}

At 3 DIV, N-, L-, and P/Q + R-type currents contributed approximately equally to peak current density (Fig. $3 B$, left). How- ever, $\mathrm{P} / \mathrm{Q}+\mathrm{R}$-type current density in the peak measure increased dramatically between 3 and 7 DIV relative to $\mathrm{N}$ - and L-type current density and thereafter remained relatively stable and the dominant component of peak current density. N-and L-type peak current densities also tended to rise between 3 and 7 DIV, but this effect was not statistically significant (two-way ANOVA). After 7 DIV, these components of the peak also remained relatively stable.

\section{Late current density}

The slowly inactivating late components exhibited markedly different profiles relative to peak density measures (Fig. 3B, right). The three late components increased significantly between 3 and 7 DIV, with the $\mathrm{P} / \mathrm{Q}+\mathrm{R}$ and $\mathrm{L}$ types increasing somewhat more than the $\mathrm{N}$ type. After $7 \mathrm{DIV}$, the $\mathrm{N}$ - and $\mathrm{P} / \mathrm{Q}+\mathrm{R}$-type late current densities remained relatively stable, increasing only $\sim 10-$ $20 \%$. However, the L-type contribution to the late current diverged substantially from the other two components, particularly after 14 DIV. By 21 DIV L-type current density was nearly double its 7 DIV value ( $p<0.05$, two-way ANOVA). Thus, after 7 DIV, the late L-type current was the only current density component that exhibited a clear, statistically significant increase.

\section{Nimodipine sensitivity over age in culture}

It is possible that the apparent increase in L-type current seen over age in culture could reflect, in part, an increase in nimodipine sensitivity rather than amount of L-type current (e.g., the 10 $\mu \mathrm{M}$ nimodipine concentration might not be saturating at earlier age points). To test this, we performed concentration-response experiments in which six or seven cells per age group $(3,7,14$, and $21 \mathrm{DIV})$ were exposed sequentially to $0.001,0.01,0.1,1$, and 10 $\mu \mathrm{M}$ nimodipine in a constant $0.1 \%$ EtOH bath solution.

These studies confirmed the approximately two-fold agedependent increase in maximal current density inhibited by nimodipine $\left(I_{\max }\right)$ and, in addition, revealed no age-dependent change in nimodipine sensitivity $\left(I C_{50}\right)$ (Fig. 4, Table 1$)$. Furthermore, the $10 \mu \mathrm{M}$ nimodipine concentration was saturating at all ages. The increase in $I_{\max }$ values was significant between 3 and 7 as well as 14 and 21 DIV (Table 1), whereas $I C_{50}$ values did not differ significantly at any age point.

\section{G-protein-coupled inhibition of $\mathbf{C a}^{2+}$ channel current}

Baclofen, a selective $\mathrm{GABA}_{\mathrm{B}}$ agonist, was used to determine whether neurotransmitter-mediated G-protein inhibition of $\mathrm{Ca}^{2+}$ channels also changed with age in culture during the relative decrease in $\mathrm{G}$-protein-sensitive current ( $\mathrm{N}$ and $\mathrm{P} / \mathrm{Q}+\mathrm{R}$ type). In these studies, GTP (0.5 mM; Tris salt) was added to the intracellular recording solution.

Although a number of neurotransmitters inhibit $\mathrm{Ca}^{2+}$ channel currents through the membrane-delimited pathway in brain neurons, inhibition by the $\mathrm{GABA}_{\mathrm{B}}$ receptor is particularly pronounced and well characterized in hippocampus (Dutar and Nicoll, 1988; Hirata et al., 1995; Frank et al., 1996). However, to confirm that baclofen inhibition was $\mathrm{G}_{\mathrm{i} / \mathrm{o}}$-protein-mediated (Hescheler et al., 1987; Wickman and Clapham, 1995) in our preparation, we examined the effects of pertussis toxin (PTX), a selective, irreversible blocker of $\mathrm{G}_{\mathrm{i} / \mathrm{o}}$ (Gilman, 1987). Sister cultures (7-14 DIV) were incubated overnight in PTX $(0.1 \mathrm{mg} / \mathrm{ml})$ or BSA $(0.1 \mathrm{mg} / \mathrm{ml})$. PTX pretreatment fully blocked baclofenmediated inhibition (Fig. $5 A$ ): baclofen inhibited $34.1 \pm 1.9 \%$ of peak current in BSA-pretreated dishes $(n=7)$ and $1.2 \pm 1.5 \%$ of peak current in PTX-pretreated dishes $(n=7)$. A two-way ANOVA for repeated measures showed a significant main effect 


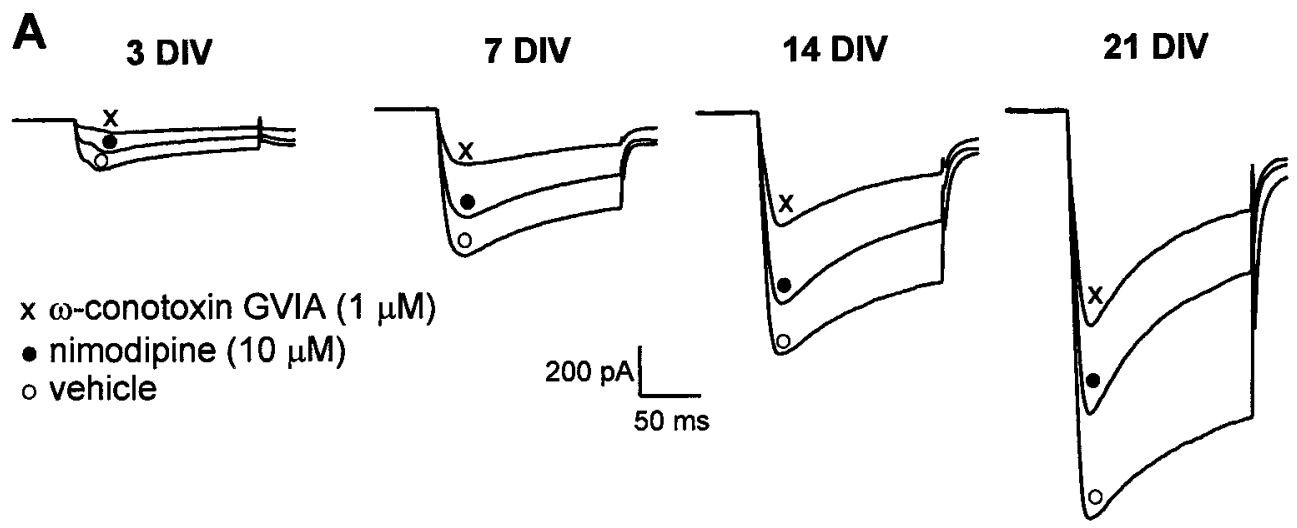

B

Figure 3. Pharmacological dissection of whole-cell $\mathrm{Ca}^{2+}$ channel current: a different profile of functional $\mathrm{Ca}^{2+}$ channel current types with age in culture. $A$, Averaged current records of cells aged 3, 7, 14, and 21 DIV recorded in vehicle $(0.1 \% \mathrm{EtOH}$ and $0.1 \mathrm{mg} / \mathrm{ml}$ cytochrome $c$ ), after the addition of $10 \mu \mathrm{M}$ nimodipine, and after the further addition of $1 \mu \mathrm{M}$ $\omega$-conotoxin GVIA. $B$, Capacitancenormalized nimodipine-sensitive current $(L)$, $\omega$-conotoxin GVIA-sensitive current $(N)$, and current unaffected by these blockers $(P / Q+R)$ revealed different age-dependent profiles at peak (left panel) and late (right panel) portions of the current record.

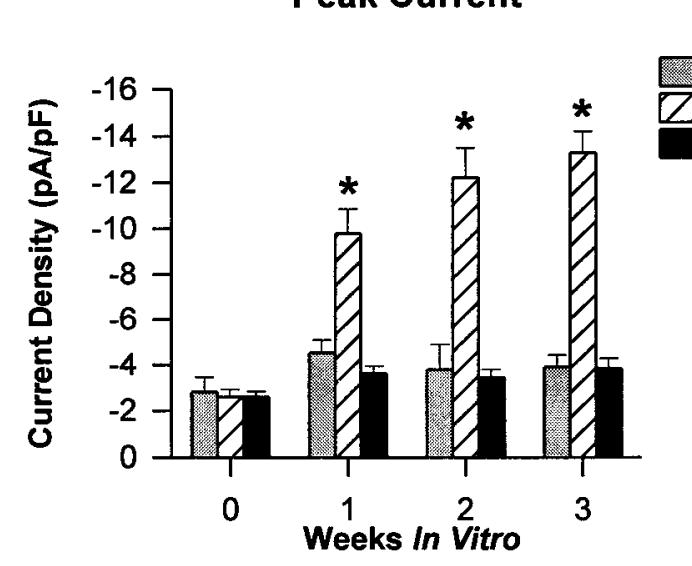

Late Current

of baclofen exposure ( $p<0.001)$, as well as a significant interaction between PTX and baclofen exposure $(p<0.005)$. Of interest was the observation that $\mathrm{Ca}^{2+}$ channel current amplitude after 24 hr PTX exposure but before baclofen application was not different in PTX- and BSA-pretreated dishes. Thus, these results confirm $G_{i / o}$ mediation and also indicate that $G_{i / o}$ proteins do not maintain tonic inhibition of $\mathrm{Ca}^{2+}$ channel current in these neurons (Zhang et al., 1996).

To confirm the selectivity of this inhibitory pathway for nonL-type currents, channel type selectivity of G-protein-coupled inhibition was also tested in this preparation. Cells aged 6 DIV were pretreated either with vehicle or $10 \mu \mathrm{M}$ nimodipine for $5 \mathrm{~min}$ before recording. After stable current was recorded (150 msec voltage steps from -70 to $+10 \mathrm{mV}$ applied every $30 \mathrm{sec}$ ), baclofen $(100 \mu \mathrm{M})$ was perfused onto the cell, and postbaclofen current was recorded. The percent of peak current inhibited by baclofen (Fig. $5 B$ ) was greater in the presence of nimodipine $(49.2 \pm 1.2 \%)$ than in its absence $(37 \pm 4 \%)$. The greater baclofen sensitivity of $\mathrm{Ca}^{2+}$ currents after removal of the L-type component confirms extensive evidence (Plummer et al., 1991; Dolphin, 1995) that L-type VSCCs are generally insensitive to membrane-delimited G-protein-mediated inhibition.

\section{G-protein-coupled inhibition of $\mathrm{Ca}^{2+}$ channel current with age in culture}

The effects of baclofen on sister cultures were investigated as above at $7(n=12), 14(n=12)$, and $21(n=11)$ DIV. Baclofen-sensitive $\mathrm{Ca}^{2+}$ channel current declined significantly between 7 and 21 DIV (Fig. 6A). Furthermore, when corrected

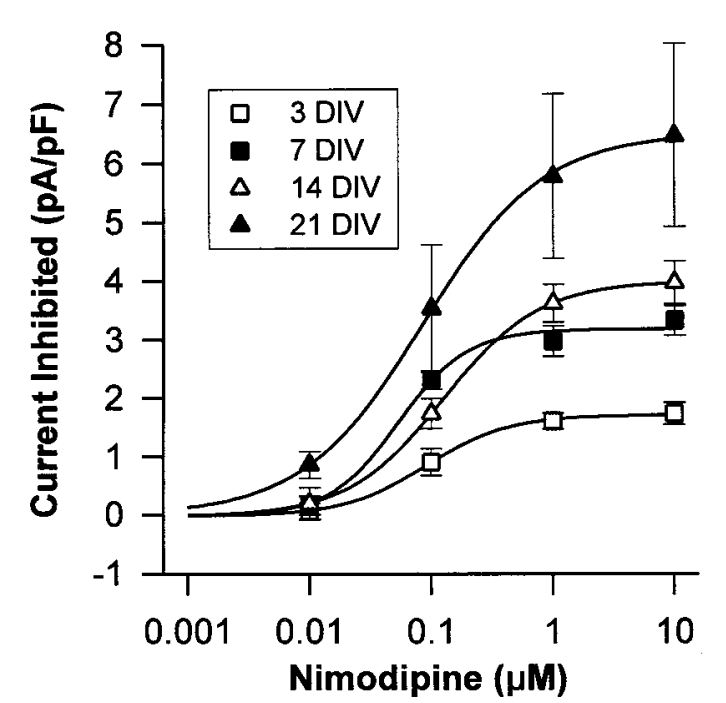

Figure 4. Age in culture did not alter concentration dependence of nimodipine inhibition of $\mathrm{Ca}^{2+}$ channel current. Semilog concentrationresponse graph is shown for six or seven cells per age group exposed to control and five concentrations of nimodipine. Nimodipine-sensitive late current density is plotted as a function of the log of nimodipine concentration. Nonlinear fits (see Materials and Methods) and means \pm SEM for each age group are plotted. Resulting fit parameters are shown in Table 1. 


Table 1. Results of nimodipine concentration-effect experiment
\begin{tabular}{lcccc} 
Parameter & $3 \mathrm{DIV}$ & $7 \mathrm{DIV}$ & $14 \mathrm{DIV}$ & $21 \mathrm{DIV}$ \\
\hline$I_{\max }$ & $1.73 \pm 0.24^{*}$ & $3.19 \pm 0.2$ & $4.01 \pm 0.425$ & $6.50 \pm 1.1^{*}$ \\
$\mathrm{IC}_{50}(\mathrm{nM})$ & $92 \pm 3$ & $54 \pm 14$ & $125 \pm 37$ & $84 \pm 69$ \\
\hline
\end{tabular}

Values are \pm SE of the fit.

*Significant difference from all other $I_{\max }$ measures (see Materials and Methods).

for cell size, the absolute current density (Fig. 6B, left) and the percent of peak current density (Fig. 6B, right) that were baclofen-sensitive decreased substantially with age in culture (Fig. $6 B)(p<0.005$, ANOVA). Only $\sim 2 \mathrm{pA} / \mathrm{pF}$ was sensitive to baclofen by 21 DIV, or $\sim 10 \%$ of total current density, in comparison with nearly $6 \mathrm{pA} / \mathrm{pF}(40 \%)$ at 7 DIV (Fig. $6 B$ ). To assess whether the decline in baclofen sensitivity is simply a reflection of the relative decrease in $\mathrm{N}$-type current, the $\mathrm{N}$-type peak current density is replotted (from Fig. $3 B$ ) side-by-side with baclofeninhibited current in Figure $6 B$ for comparison purposes. These comparisons show clearly that the decrease in G-protein-coupled inhibition from 7 to 21 DIV is much greater than could be accounted for simply by a decrease in the amount or fraction of G-protein-sensitive N-type current (or P/Q + R type; e.g., Fig. $3 B$ ). Therefore, the decrease in baclofen-sensitive current reflects a reduction of inhibitory regulation of $\mathrm{Ca}^{2+}$ current that, at least on the surface, is separate from the shift in relative density.

To determine whether the decreased inhibition reflected changes at sites at/or preceding receptor-G-protein interactions (e.g., possible reduced concentrations of functional receptors or altered receptor-G-protein coupling) rather than at G-protein$\mathrm{Ca}^{2+}$ channel interactions, cells were recorded at 7 and 21 DIV with pipettes containing $0.5 \mathrm{~mm}$ GTP or guanosine 5'-3-O(thio)triphosphate (GTP $\gamma \mathrm{S}$, a nonhydrolyzable analog of GTP that irreversibly activates G-proteins). Use of GTP $\gamma$ S effectively circumvents receptors and receptor-G-protein coupling for G-protein-mediated effects.

GTP $\gamma$ S significantly reduced peak current density in 7 DIV but not in 21 DIV neurons (Fig. 7, bottom, left). The percent of total current density inhibited was reduced from $59 \%$ (7 DIV) to $24 \%$ (21 DIV) (Fig. 7, bottom, right). Thus, the primary site of declining G-protein-coupled inhibition of VSCCs appears to lie at or after the G-protein-channel interaction process.

\section{DISCUSSION}

The two major new findings in this study are that in primary hippocampal neurons (1) L-type current density appears to be the only type of high-threshold VSCC current density that increases substantially with age after 7 DIV; and (2) increased influx of $\mathrm{Ca}^{2+}$ through non-L-VSCCs may nevertheless develop with age after 7 DIV. This latter effect can occur through the novel age-dependent mechanism of declining neurotransmittermediated, G-protein-coupled inhibition of VSCCs. Interestingly, over the same time frame, age-dependent increases in the vulnerability of cultured neurons to excitotoxic insult (Choi, 1987; Geddes et al., 1997; McDonald et al., 1997; Adamec et al., 1998) and increased concomitant $\mathrm{Ca}^{2+}$ transients have been reported (Thibault et al., 1997). Furthermore, we recently observed that nimodipine inhibits age-dependent, spontaneous cell death in cultured hippocampal neurons (Porter et al., 1997), suggesting that the present findings of a selective increase in L-type current with age in culture may have major implications for the role of VSCCs in cell death and excitotoxicity.
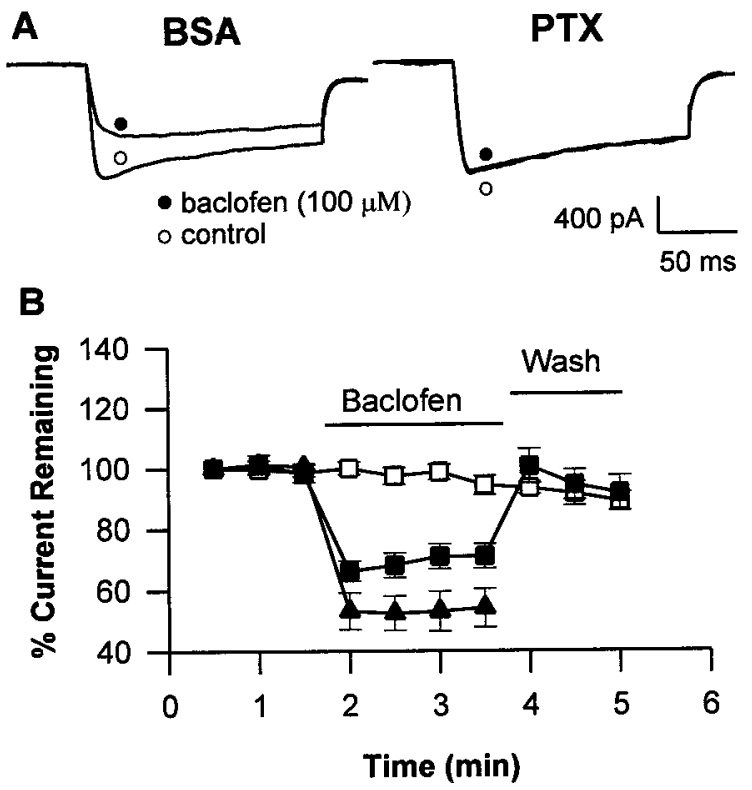

Figure 5. Baclofen-mediated inhibition of current through G-proteindependent mechanisms. $A$, Cells treated $24 \mathrm{hr}$ with $0.1 \mathrm{mg} / \mathrm{ml}$ BSA $(n=$ 7) showed normal response to baclofen. Sister cultures treated $24 \mathrm{hr}$ with $0.1 \mathrm{mg} / \mathrm{ml}$ PTX $(n=6)$ failed to respond to baclofen. Two-way ANOVA RM: baclofen, $p<0.05$; PTX, $p>0.1$; interaction, $p<0.05) B$, Time course of percentage-normalized responses. In control cells $(\mathbf{\square})$ baclofen inhibition was reversible by wash; $\mathrm{Ca}^{2+}$ channel current in PTX-treated cells $(\square)$ was not significantly altered by baclofen, and $\mathrm{Ca}^{2+}$ channel current in cells pretreated with nimodipine $(\mathbf{\Delta})(n=6)$ was significantly inhibited $(p<0.001$, paired $t$ test $)$ to a relatively greater degree than control cells.

\section{Age-dependent alterations in VSCC current density}

The present studies confirmed previous findings of an agedependent increase in L-type current density in primary cultures of hippocampal neurons (Porter et al., 1997) and extended this observation here to show that after 7 DIV a similar increase does not occur in other high-threshold VSCC types. When current amplitudes were normalized for cell size, current density for the $\mathrm{N}$ and $\mathrm{P} / \mathrm{Q}+\mathrm{R}$ components increased only during the first week of culture. In contrast, the late L-type component continued to rise substantially through $21 \mathrm{DIV}$, resulting in a nearly twofold increase at 21 DIV compared with 7 DIV. This pattern occurred only in the late current component. For peak current, which was dominated by the $\mathrm{P} / \mathrm{Q}+\mathrm{R}$ component after $3 \mathrm{DIV}$, all components remained relatively stable after 7 DIV. However, it should perhaps be noted that the L-type contribution to peak current could have been partially masked. Nimodipine block of L-VSCCs is voltage-dependent and delayed in onset during a depolarizing step (Bean, 1984; Ertel and Cohen, 1994). This could lead to underestimating its contribution to the rapid peak. Nevertheless, the only clear increase in any component of current density between 7 and 21 DIV, which is the period of maximal increase in excitotoxic vulnerability, occurred in the late component of L-VSCC current density (Fig. 3).

Aging-related increases have been found in mRNA for the $\alpha_{1 \mathrm{D}}$ (and possibly the $\alpha_{1 C}$ ) subunit of the L-VSCC (with no change in $\beta_{1 \mathrm{~b}}$ subunit mRNA), and accompany the age-related increases in L-type channel density both in vitro (Porter et al., 1997) and in vivo (Thibault and Landfield, 1996; Herman et al., 1998). This suggests that selectively enhanced gene expression, perhaps re- 


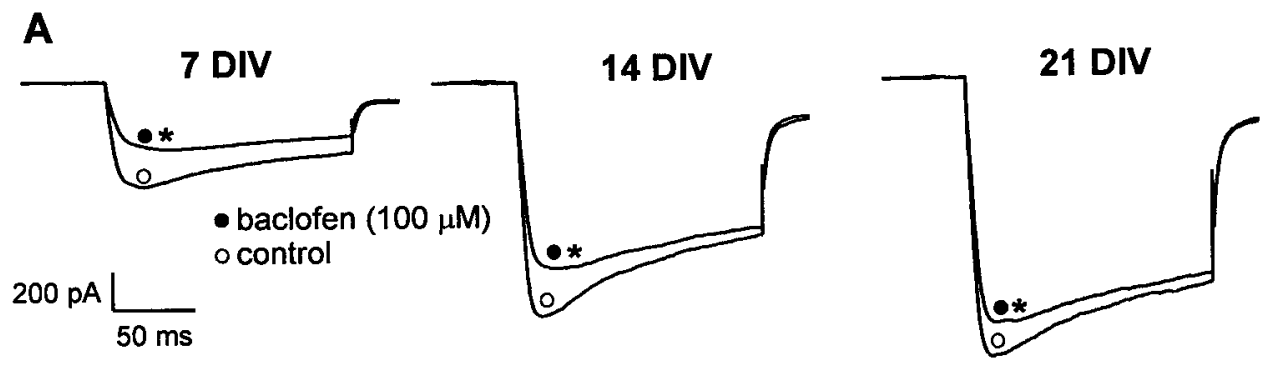

Figure 6. Decline in baclofen-sensitive current with age in culture. $A$, Averaged waveforms from $7(n=12), 14(n=11)$, and $21(n=10)$ DIV neurons before and after $100 \mu \mathrm{M}$ baclofen application. Baclofen significantly inhibited current in all groups (two-way ANOVA RM; *post hoc Tukey's comparison, $p<0.05)$. $B$, Baclofen-sensitive current density was significantly reduced with age in culture (one-way ANOVA, $p<0.001$ ). To facilitate comparison with previous data, $\mathrm{N}$-type peak current density ( gray bars) from Figure $3 B$ is replotted.
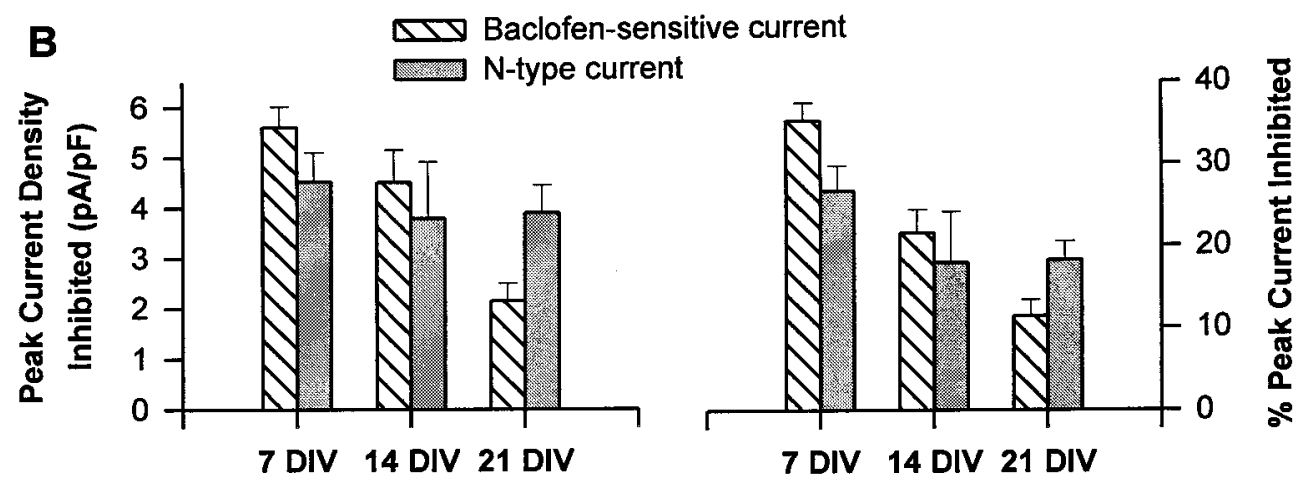

7 DIV
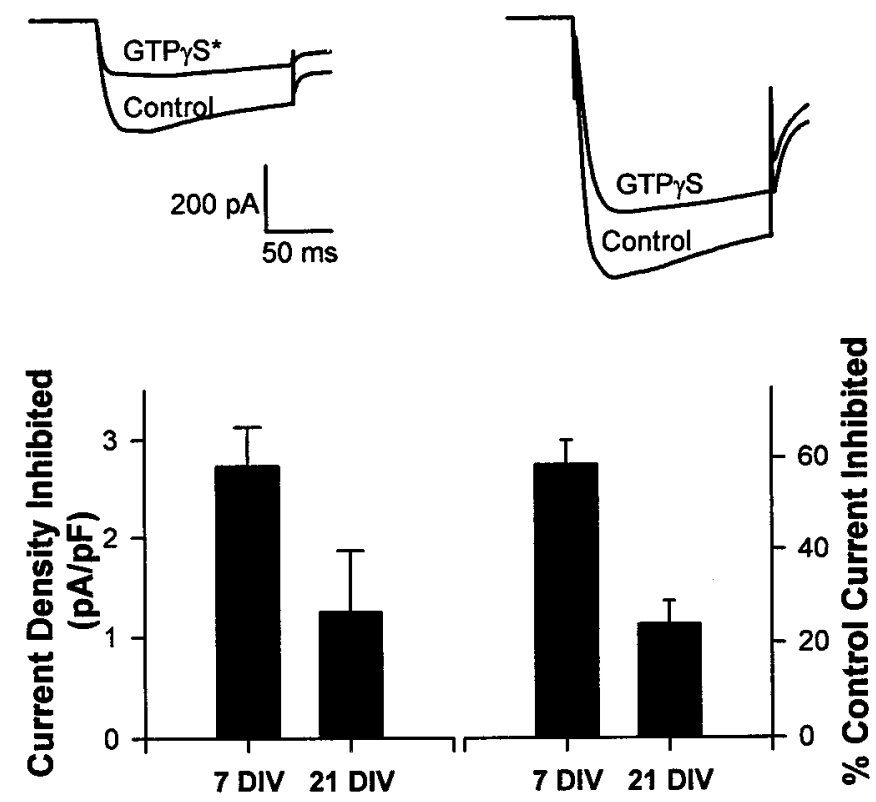

Figure 7. GTP $\gamma \mathrm{S}$-sensitive current decreases with age in culture. Top, Averaged whole-cell current from control and GTP $\gamma$ S-treated cells at 7 and 21 DIV ( $n=8-9$ per group). Bottom, Peak current density (left $)$ and percent of control peak current (right) inhibited by intracellular GTP $\gamma \mathrm{S}$ both demonstrate a significant inhibition of current by GTP $\gamma \mathrm{S}$ in 7 but not 21 DIV cultured cells $(p<0.05$; two-way ANOVA). To facilitate comparisons with Figure 6, the amount and percent of current inhibited was calculated relative to the mean of the untreated control group.

sulting from an accelerated aging or developmental genomic program, could underlie some aspects of the shift in VSCC current density. Alternatively, the enhanced expression might be a response to cellular stimuli signaling declining neuronal viability, perhaps somewhat analogous to the selective changes in gene expression seen on a shorter time scale after injury (Kelley and Steward, 1997).

\section{G-protein-coupled inhibition of non-L-type $\mathrm{Ca}^{2+}$ channel current}

Excitatory as well as inhibitory neurotransmitters can trigger G-protein-coupled inhibition of VSCCs (see introductory remarks). Glutamate, for example, has been found to inhibit $\mathrm{N}$ - and P-type VSCCs through metabotropic glutamate receptors (mGluRs) in several neuronal types (Sahara and Westbrook, 1993; Hay and Kunze 1994; Choi and Lovinger, 1996; Stefani et al., 1998). However, excitatory neurotransmitters, such as glutamate, also induce major postsynaptic $\mathrm{Ca}^{2+}$ influx, both directly through their own ionotropic receptors and indirectly, through depolarization of VSCCs (Brown and Jaffe, 1994; Magee and Johnston, 1995; Bollmann et al., 1998). Consequently, the mGluR-mediated inhibition of VSCCs appears to act in some ways as a negative feedback mechanism to regulate $\mathrm{Ca}^{2+}$ elevation.

Moreover, although they are present postsynaptically, non-LVSCCs have also been widely implicated in presynaptic $\mathrm{Ca}^{2+}$ dependent transmitter release (Wheeler et al., 1994; Wu and Saggau, 1994; Magee and Johnston, 1995; Scholz and Mitter, 1995; Mochida et al., 1996; Wu et al., 1998). Therefore, impaired G-protein inhibition of presynaptic VSCC would lead to enhanced transmitter release from either inhibitory or excitatory terminals. In the case of glutamatergic terminals, this could be particularly relevant to age-dependent changes in excitotoxic vulnerability. Several types of mGluR receptors are localized presynaptically and appear to act in part by reducing glutamate release (Conn et al., 1998; Moroni et al., 1998). Thus, the agedependent decline in G-protein-coupled inhibition of VSCCs seen here would likely result in greater presynaptic $\mathrm{Ca}^{2+}$ influx at glutamatergic terminals, which, in turn, could contribute to greater release and heightened excitotoxicity.

The decline in G-protein inhibition was not accounted for simply by a relative decrease in G-protein-sensitive $\mathrm{N}$ or $\mathrm{P} / \mathrm{Q}+\mathrm{R}$ type VSCCs (Figs. 3B, 6), indicating that the specific coupling pathway was somehow altered. There are multiple mechanisms through which G-protein regulation could be altered with age (Beech et al., 1992; Luebke and Dunlap, 1994; Rhim et al., 1996). 
In the present studies, baclofen-mediated $\mathrm{Ca}^{2+}$ channel current inhibition met several criteria (e.g., PTX sensitivity and kinetic slowing) that indicate a membrane-delimited, $\mathrm{G}_{\mathrm{i} / \mathrm{o}}$-proteincoupled inhibition (Cox and Dunlap, 1992; Boland and Bean, 1993; Hille, 1994).

Membrane-delimited inhibition of $\mathrm{N}$ and $\mathrm{P} / \mathrm{Q}+\mathrm{R}$ type VSCCs appears to depend on an interaction of the $\mathrm{G}_{\beta \gamma}$ heterodimer with the $\alpha_{1}$ subunit of the $\mathrm{Ca}^{2+}$ channel (Herlitze et al., 1996; Ikeda, 1996; Zamponi and Snutch, 1998), possibly in competition with the VSCC $\beta$ subunit (Bourinet et al., 1996; Qin et al., 1997; Roche and Treistman, 1998). In the present studies, the clear similarity of the age reduction in GTP $\gamma \mathrm{S}$-sensitive current over age (Fig. 7) to the reduction of baclofen-sensitive current (Fig. 6) indicates that the primary deficit is probably downstream of the receptorG-protein coupling stage, possibly involving the coupling of $\mathrm{G}_{\beta \gamma}$ and the VSCC $\alpha_{1}$ subunit (Qin et al., 1997; Zamponi and Snutch, 1998). Although this coupling mechanism seems unlikely to be influenced by the concomitant increase in L-type channel membrane density, some form of density-dependent cell surface redistribution of non-L-VSCCs away from G-proteins cannot be ruled out.

\section{Long-term culture as a potential model system for aging-like changes}

The long-term culture model and the in vivo brain obviously age over very different time scales and life cycles, and the culture system clearly cannot be viewed simply as "aging in a dish." As noted, however, the long-term culture shows several patterns of age-dependent increase in $\mathrm{Ca}^{2+}$ channel currents, L-VSCC membrane density, and $\alpha_{1 \mathrm{D}}$ mRNA expression (Porter et al., 1997), among other variables, that are remarkably similar in pattern to increases found during aging in vivo (Landfield et al., 1989; Moyer et al., 1992; Disterhoft et al., 1994; Campbell et al., 1996; Thibault and Landfield, 1996; Herman et al., 1998). It seems possible, therefore, that selective gene expression or some other aspects of in vivo aging might be accelerated and expressed much earlier in vitro than in vivo, perhaps because of differences in the environmental milieu of growth and inhibitory factors, and/or reduced contact inhibition. At the least, the in vitro culture model may be of considerable value for studying the relationship between time-dependent changes in $\mathrm{Ca}^{2+}$-regulating mechanisms and altered neuronal vulnerability.

The finding here that a G-protein-coupled process declines with age appears to further strengthen this culture model for aging studies, because a decline in some G-protein-coupled responses (e.g., $G_{\alpha}$ subunit-activated processes), has been observed in brain aging and Alzheimer's disease (Wang et al., 1992; Roth et al., 1995; Cowburn et al., 1996). Although the membranedelimited $\left(\mathrm{G}_{\beta \gamma}\right.$-mediated) pathway has not yet been studied in aging animals, the present results suggest the intriguing hypothesis, and testable prediction, that a deficit in this pathway will also be found in the neurons of aged animals.

\section{Functional implications}

The present studies have identified selective and novel agedependent mechanisms through which $\mathrm{Ca}^{2+}$ influx through both L-type and non-L-type VSCCs can be increased in neurons. These findings raise the possibility that separate $\mathrm{Ca}^{2+}$ influx pathways could act together to alter function or vulnerability with age. On the other hand, the functional consequences of increased $\mathrm{Ca}^{2+}$ influx through these separate pathways could be very different, because it is becoming increasingly evident that dissimilar routes of $\mathrm{Ca}^{2+}$ influx can have substantially different effects (Tymianski et al., 1993; Gallin and Greenberg, 1995; Bito et al., 1997; Bollmann et al., 1998). Influx through L-type VSCCs, for example, appears to be considerably more effective at inducing gene expression than influx through other ligand- and other voltage-gated $\mathrm{Ca}^{2+}$ channels (Gallin and Greenberg, 1995; Bito et al., 1997).

As noted above, one other major difference in these influx pathways is that, unlike L-VSCCs, non-L-VSCCs can also regulate presynaptic release during neurotransmission. Thus, decreased G-protein-mediated inhibition of non-L-VSCCs presynaptically could result in elevated (and disruptive) release of multiple transmitters, including glutamate. The latter, in turn, could be one factor in enhanced vulnerability with age in culture.

\section{REFERENCES}

Abele AE, Scholz KP, Scholz WK, Miller RJ (1990) Excitotoxicity induced by enhanced excitatory neurotransmission in cultured hippocampal pyramidal neurons. Neuron 2:413-419.

Adamec C, Didier M, Nixon RA (1998) Developmental regulation of the recovery process following glutamate-induced calcium rise in rodent primary neuronal cultures. Brain Res Dev Brain Res 108:101-110.

Ankarcrona M, Dypbukt JM, Bonfoco E, Zhitovsky E, Orrenius S, Lipton SA, Nicotera P (1995) Glutamate-induced neuronal death: a succession of necrosis or apoptosis depending on mitochondrial function. Neuron 15:961-973.

Armitage P, Berry G (1990) Statistical methods in scientific research. Boston: Blackwell Scientific.

Armstrong CM, Gilly WF (1992) Access resistance and space-clamp problems associated with whole-cell patch clamping. Methods Enzymol 207:100-122.

Banker GA, Cowan WM (1977) Rat hippocampal neurons in dispersed cell culture. Brain Res 126:397-342.

Bargas J, Howe A, Eberwine J, Cao Y, Surmeier DJ (1994) Cellular and molecular characterization of $\mathrm{Ca}^{2+}$ channel currents in acutely isolated, adult rat neostriatal neurons. J Neurosci 14:6667-6686.

Barnes CA (1994) Normal aging: regionally specific changes in hippocampal synaptic transmission. Trends Neurosci 17:13-18.

Barnes CA, McNaughton BL (1980) Physiological compensation for loss of afferent synapses in rat hippocampal granule cells during senescence. J Physiol (Lond) 309:473-485.

Basarsky TA, Parpura V, Haydon PG (1994) Hippocampal synaptogenesis in cell culture: developmental time course of synapse formation, calcium influx, and synaptic protein distribution. J Neurosci 14:6402-6411.

Bean BP (1984) Nitrendipine block of cardiac calcium channels: high affinity binding to the inactivated state. Proc Natl Acad Sci USA 81:6388-6392.

Bean BP (1989) Neurotransmitter inhibition of neuronal calcium currents by changes in channel voltage dependence. Nature 340:153-156.

Beech DJ, Bernheim L, Hille B (1992) Pertussis toxin and voltagedependence distinguish multiple pathways modulating calcium channels of sympathetic neurons. Neuron 8:97-106.

Bickford-Wimer PC, Miller JA, Freedman R, Rose GM (1988) Agerelated reduction in responses of rat hippocampal neurons to locally applied monoamines. Neurobiol Aging 9:173-179.

Birnbaumer L, Campbell KP, Catterall WA, Harpold MM, Hofmann F, Horne WA, Mori Y, Schwartz A, Snutch TP, Tanabe T, Tsien RW (1994) The naming of voltage-gated calcium channels. Neuron 13:505-506.

Bito H, Deisseroth K, Tsien RW (1997) $\mathrm{Ca}^{2+}$-dependent regulation in neuronal gene expression. Curr Opin Neurobiol 7:419-429.

Boland LM, Bean BP (1993) Modulation of N-type calcium channels in bullfrog sympathetic neurons by luteinizing hormone-releasing hormone: kinetics and voltage dependence. J Neurosci 13:516-533.

Boland LM, Morrill JA, Bean BP (1994) $\omega$-Conotoxin block of calcium channels in frog and rat sympathetic neurons. J Neurosci 14:5011-5027.

Bollmann JH, Helmchen F, Borst JGG, Sakmann B (1998) Postsynaptic $\mathrm{Ca}^{2+}$ influx mediated by three different pathways during synaptic transmission at a calyx-type synapse. J Neurosci 18:10409-10419. 
Bourinet E, Soong TW, Stea A, Snutch TP (1996) Determinants of the G-protein dependent opioid modulation of neuronal calcium channels. Proc Natl Acad Sci USA 93:1486-1491.

Brown TH, Jaffe DB (1994) Calcium imaging in hippocampal neurons using confocal microscopy. In: Calcium hypothesis of aging and dementia, Annals of the New York Academy of Sciences, Vol 747 (Disterhoft JF, Gispen WH, Traber J, Khachaturian ZS, eds), pp 313-324. New York: NewYork Academy of Sciences.

Cahalan M, Neher E (1992) Patch-clamp techniques: an overview. Methods Enzymol 207:3-14.

Campbell LW, Hao SY, Thibault O, Blalock EM, Landfield PW (1996) Aging changes in voltage-gated calcium currents in hippocampal CA1 neurons. J Neurosci 16:6286-6295.

Carnevale NT, Tsai KY, Claiborne BJ, Brown TH (1997) Comparative electrotonic analysis of three classes of rat hippocampal neurons. J Neurophysiol 78:703-720.

Catterall WA (1995) Structure and function of voltage-gated ion channels. Annu Rev Biochem 64:493-531.

Choi DW (1987) Ionic dependence of glutamate neurotoxicity in cortical cell culture. J Neurosci 7:369-379.

Choi DW (1988) Calcium-mediated neurotoxicity: relationship to specific channel types and role in ischemic damage. Trends Neurosci 11:465-469.

Choi DW, Lovinger DM (1996) Metabotropic glutamate receptor modulation of voltage-gated $\mathrm{Ca}^{2+}$ channels involves multiple receptor subtypes in cortical neurons. J Neurosci 16:36-45.

Conn PJ, Bradley SR, Macek TA, Winder DG, Gereau RW (1998) Physiological roles of multiple metabotropic glutamate receptor subtypes in the hippocampus. In: Metabotropic glutamate receptors and brain function (Moroni R, Nicoletti F, Pellegrini-Giampietro DE, eds), pp 87-98. Miami: Portland.

Cowburn RF, Fowler CJ, O'Neill C (1996) Neurotransmitter receptor/ G-protein mediated signal transduction in Alzheimer's disease brain. Neurodegeneration 5:483-488.

Cox DH, Dunlap K (1992) Pharmacologic discrimination of N-type from L-type calcium current and its selective modulation by transmitters. J Neurosci 12:906-914.

Currie KP, Fox AP (1997) Comparison of N- and P/Q-type voltagegated calcium channel current inhibition. J Neurosci 17:4570-4579.

Delcour A, Tsien RW (1993) Altered prevalence of gating in neurotransmitter inhibition of N-type calcium channels. Science 259:980-984.

Diochet S, Richard S, Baldy-Moulinier M, Nargeot J, Valmier J (1995) Dihydropyridines, phenylalkylamines and benzothiazepines block N-, P/Q-, and R-type calcium currents. Pflügers Arch 431:10-19.

Disterhoft JF, Moyer JR, Thompson LT (1994) The calcium rationale in aging and Alzheimer's disease: evidence from an animal model of normal aging. In: Calcium hypothesis of aging and dementia, Annals of the New York Academy of Sciences, Vol 747 (Disterhoft JF, Gispen WH, Traber J, Khachaturian ZS, eds), pp 382-406. New York: New York Academy of Sciences.

Dolphin AC (1995) Voltage-dependent calcium channels and their modulation by neurotransmitters and G proteins. Exp Physiol 80:1-36.

Dubinsky JM, Rothman SM (1991) Intracellular calcium concentrations during "chemical hypoxia" and excitotoxic neuronal injury. J Neurosci 11:2545-2551.

Dutar P, Nicoll RA (1988) A physiologic role for GABA $_{B}$ receptors in the central nervous system. Nature 332:156-158.

Eliot LS, Johnston D (1994) Multiple components of calcium current in acutely dissociated dentate gyrus granule neurons. J Neurophysiol 72:762-777.

Ertel EA, Cohen CJ (1994) Voltage-dependent interactions: the influence and significance of membrane potential on drug receptor interactions. Drug Dev Res 33:203-213.

Fisher RE, Gray R, Johnston D (1990) Properties and distribution of single voltage-gated calcium channels in adult hippocampal neurons. J Neurophysiol 64:91-104.

Forti L, Pietrobon D (1993) Functional diversity of L-type calcium channels in rat cerebellar neurons. Neuron 10:437-450.

Frandsen A, Schousboe A (1990) Development of excitatory amino acid induced cytotoxicity in cultured neurons. Int J Dev Neurosci 8:209-216.

Frank C, Engert F, Tokutomi N, Lux HD (1996) Different effects of baclofen and GTP $\gamma \mathrm{S}$ on voltage-activated $\mathrm{Ca}^{2+}$ currents in rat hippocampal neurons in vitro. Eur J Pharmacol 295:87-92.

Gallin WJ, Greenberg ME (1995) Calcium regulation of gene expres- sion in neurons: the mode of entry matters. Curr Opin Neurobiol $5: 367-374$.

Geddes JL, Landfield PW, Porter NM (1997) Enhanced vulnerability to excitotoxicity in hippocampal neurons with age in culture. Soc Neurosci Abstr 23:1711.

Geinisman Y, deToledo-Morrell L, Morrell F (1994) Comparison of structural synaptic modifications induced by long-term potentiation in the hippocampal dentate gyrus of young and adult rats. In: Calcium hypothesis of aging and dementia, Annals of the New York Academy of Sciences, Vol 747 (Disterhoft JF, Gispen WH, Traber J, Khachaturian ZS, eds), pp 452-466. New York: New York Academy of Sciences.

Gilman AG (1987) G proteins: transducers of receptor generated signals. Annu Rev Biochem 56:615-649.

Groul DL, Deal CR, Yool AJ (1992) Developmental changes in calcium conductances contribute to the physiological maturation of cerebellar Purkinje neurons in culture. J Neurosci 12:2838-2848.

Hamill OP, Marty A, Neher E, Sakmann B, Sigworth FJ (1981) Improved patch-clamp techniques for high-resolution current recordings from cells and cell-free membrane patches. Pflügers Arch 391:85-100.

Hay M, Kunze DL (1994) Glutamate metabotropic receptor inhibition of voltage-gated calcium currents in visceral sensory neurons. J Neurophysiol 72:421-430.

Herman JP, Chen K-C, Booze R, Landfield PW (1998) Up-regulation of $\alpha_{1 \mathrm{D}} \mathrm{Ca}^{2+}$ channel subunit mRNA expression in the hippocampus of aged F344 rats. Neurobiol Aging 19:581-587.

Herlitze S, Garcia DE, Mackie K, Hille B, Scheuer T, Catterall W (1996) Modulation of $\mathrm{Ca}^{2+}$ channels by G-protein subunits. Nature 380:258-262.

Hescheler J, Rosenthal W, Trautwein W, Schultz G (1987) The GTP binding protein, $G_{o}$, regulates neuronal calcium channels. Nature 325:445-447.

Hille B (1994) Modulation of ion-channel function by G-protein-coupled receptors. Trends Neurosci 17:531-536.

Hirata K, Ohno-Shosaku T, Sawada S, Yamamoto C (1995) Baclofen inhibits GABAergic transmission after treatment with type-specific calcium channel blockers in cultured rat hippocampal neurons. Neurosci Lett 187:205-208.

Hoffer BJ, Rose G, Parfitt K, Freedman R, Bickford-Wimer PC (1988) Age-related changes in cerebellar noradrenergic function. In: Central determinants of age-related declines in motor function, Annals of the New York Academy of Sciences, Vol 515 (Joseph JA, ed), pp 269-286. New York: New York Academy of Sciences.

Holz IV GG, Rane SG, Dunlap K (1986) GTP-binding proteins mediate transmitter inhibition of voltage-dependent calcium channels. Nature 319:670-672.

Ikeda SR (1996) Voltage-dependent modulation of N-type calcium channels by G-protein subunits Nature 380:255-258.

Ishibashi H, Rhee JS, Akaike N (1995) Regional difference of high voltage-activated $\mathrm{Ca}^{2+}$ channels in rat CNS neurones. NeuroReport 6:1621-1624.

Johnston D, Brown TH (1983) Interpretation of voltage-clamp measurements in hippocampal neurons. J Neurophysiol 50:464-486.

Kang J, Huguenard JR, Prince DA (1996) Development of BK channels in neocortical pyramidal neurons. J Neurophysiol 76:188-198.

Kavalali ET, Plummer MR (1994) Selective potentiation of a novel calcium channel in rat hippocampal neurones. J Physiol (Lond) 480:475-484.

Kelley MS, Steward O (1997) Injury-induced physiological events that may modulate gene expression in neurons and glia. Rev Neurosci 8:147-177.

Khachaturian ZS (1994) Calcium hypothesis of Alzheimer's disease and brain aging. In: Calcium hypothesis of aging and dementia, Annals of the New York Academy of Sciences, Vol 747 (Disterhoft JF, Gispen WH, Traber J, Khachaturian ZS, eds), pp 1-11. New York: New York Academy of Sciences.

Kimura M, Sawada K, Miyagawa T, Kuwada M, Katayama, K, Nishizawa Y (1998) Role of glutamate receptors and voltage-dependent calcium and sodium channels in the extracellular glutamate/aspartate accumulation and subsequent neuronal injury induced by oxygen/glucose deprivation in hippocampal neurons. J Pharmacol Exp Ther 285:178-185. Landfield PW, Pitler TA, Applegate MD (1986) The effects of high $\mathrm{Mg}^{2+}$-to- $\mathrm{Ca}^{2+}$ ratios on frequency potentiation in hippocampal slices of young and aged rats. J Neurophysiol 1986:56:797-811.

Landfield PW, Campbell LW, Hao SY, Kerr SD (1989) Aging related increases in voltage-sensitive, inactivating calcium currents in rat hip- 
pocampus: implications for mechanisms of brain aging and Alzheimer's disease. In: Calcium, membranes, aging, and Alzheimer's disease, Annals of the New York Academy of Sciences, Vol 568 (Khachaturian ZS, Cotman CW, Pettegrew JW, eds), pp 95-105. New York: New York Academy of Sciences.

Lipton SA (1994) AIDS-related dementia and calcium homeostasis. In: Calcium hypothesis of aging and dementia, Annals of the New York Academy of Sciences, Vol 747 (Disterhoft JF, Gispen WH, Traber J, Khachaturian ZS, eds), pp 205-224. New York: New York Academy of Sciences.

Llinás R, Sugimori M, Lin JW, Cherksey B (1989) Blocking and isolation of a calcium channel from neurons in mammals and cephalopods utilizing a toxin fraction (FTX) from funnel-web spider poison. Proc Natl Acad Sci USA 86:1689-1693.

Lorenzon NM, Foehring RC (1995) Characterization of pharmacologically identified voltage-gated calcium channel currents in acutely isolated rat neocortical neurons II. J Neurophysiol 73:1443-1451.

Luebke JI, Dunlap K (1994) Sensory neuron N-type calcium channels are inhibited by both voltage-dependent and -independent mechanisms. Pflügers Arch 428:499-507.

Magee JC, Johnston D (1995) Synaptic activation of voltage-gated channels in the dendrites of hippocampal pyramidal neurons. Science 268:301-304.

Mathes C (1998) Getting acquainted with Clampex 7's membrane test. AxoBits 24:9-11.

Mattson MP, Kater SB (1987) Calcium regulation of neurite elongation and growth cone motility. J Neurosci 7:4034-4043.

Mattson MP, Wang H, Michaelis EK (1991) Developmental expression, compartmentalization, and possible role in excitotoxicity of a putative NMDA receptor protein in cultured hippocampal neurons. Brain Res 565:94-108.

Mazzanti ML, Landfield PW (1994) Ion species selectivity of currentdependent inactivation of a very long $\mathrm{Ca}^{2+}$ tail current in cultured hippocampal neurons. Soc Neurosci Abstr 20:900.

McDonald JW, Behrens MI, Chung C, Bhattacharyya T, Choi DW (1997) Susceptibility to apoptosis is enhanced in immature cortical neurons. Brain Res 759:228-232.

Mochida S, Sheng ZH, Baker C, Kobayashi H, Catterall WA (1996) Inhibition of neurotransmission by peptides containing the synaptic protein interaction site of $\mathrm{N}$-type $\mathrm{Ca}^{2+}$ channels. Neuron 17:781-788.

Moroni F, Cozzi A, Lombardi G, Leonardi P, Carfi M, Attuci S, Peruginelli F, Pellicciari R (1998) Metabotropic glutamate receptors and transmitter output: in vivo studies with new potent mGluR1 and mGluR2 antagonists. In: Metabotropic glutamate receptors and brain function (Moroni R, Nicoletti F, Pellegrini-Giampietro DE, eds), pp 225-234. Miami: Portland.

Moyer JR, Thompson LT, Black JP, Disterhoft JF (1992) Nimodipine increases excitability of rabbit CA1 pyramidal neurons in an age- and concentration-dependent manner. J Neurophysiol 68:2100-2109.

Olney JW (1986) Inciting excitotoxic cytocide among central neurons. Adv Exp Med Biol 203:631-645.

Plummer MR, Rittenhouse A, Kanevsky M, Hess P (1991) Neurotransmitter modulation of calcium channels in rat sympathetic neurons. J Neurosci 11:2339-2348.

Porter NM, Thibault O, Thibault V, Chen KC, Landfield PW (1997) Calcium channel density and hippocampal cell death with age in long-term culture. J Neurosci 17:5629-5639.

Qin N, Platano D, Olcese R, Stefani E, Birnbaumer L (1997) Direct interaction of $\mathrm{G}_{\beta \gamma}$ with a $\mathrm{C}$ terminal $\mathrm{G}_{\beta \gamma}$ binding domain of the calcium channel $\alpha 1$ subunit is responsible for channel inhibition by G-proteincoupled receptors. Proc Natl Acad Sci USA 94:8866-8871.

Randall A, Tsien RW (1995) Pharmacologic dissection of multiple types of $\mathrm{Ca}^{2+}$ channel currents in rat cerebellar granule neurons. J Neurosci 15:2995-3012.

Regan RF, Choi DW (1991) Glutamate neurotoxicity in spinal cord cell culture. Neuroscience 43:585-591.

Regan LR, Sah DWY, Bean BP (1991) $\mathrm{Ca}^{2+}$ channels in rat central and peripheral neurons: high-threshold current resistant to dihydropyridine blockers and $\omega$-conotoxin. Neuron 6:269-280.

Rhim H, Toth PT, Miller RJ (1996) Mechanisms of inhibition of calcium channels in rat nucleus tractus solitarius by neurotransmitters. $\mathrm{Br} \mathrm{J}$ Pharmacol 118:1341-1350.

Roche JP, Treistman SN (1998) $\mathrm{Ca}^{2+}$ channel $\beta_{3}$ subunit enhances voltage-dependent relief of G-protein inhibition induced by muscarinic receptor activation and $\mathrm{G}_{\beta \gamma}$. J Neurosci 18:4883-4890.
Rose GM, Gerhardt GA, Conboy GL, Hoffer BJ (1986) Age-related alterations in monoamine release from rat striatum: an in vivo electrochemical study. Neurobiol Aging 7:77-82.

Roth GS, Joseph JA, Mason RP (1995) Membrane alterations as causes of impaired signal transduction in Alzheimer's disease and aging. Trends Neurosci 18:203-208.

Roy J, Minotti S, Dong L, Figlewicz DA, Durham HD (1998) Glutamate potentiates the toxicity of mutant $\mathrm{Cu} / \mathrm{Zn}$-superoxide dismutase in motor neurons by postsynaptic calcium-dependent mechanisms. J Neurosci 18:9673-9684.

Rusanescu G, Qi H, Thomas SM, Brugge JS, Halegoua S (1995) Calcium influx induces neurite growth through a Src-Ras signaling cascade. Neuron 15:1415-1425.

Sahara Y, Westbrook GL (1993) Modulation of calcium currents by metabotropic glutamate receptor involves fast and slow kinetic components in cultured hippocampal neurons. J Neurosci 13:3041-4050.

Schmid S, Guenther E (1999) Voltage-activated calcium currents in rat retinal ganglion cells in situ: changes during prenatal and postnatal development. J Neurosci 19:3486-3494.

Scholz KP, Miller RJ (1995) Developmental changes in presynaptic calcium channels coupled to glutamate release in cultured rat hippocampal neurons. J Neurosci 15:4612-4617.

Slesinger PA, Lansman JB (1991) Reopening of $\mathrm{Ca}^{2+}$ channels in mouse cerebellar neurons at resting membrane potentials during recovery from inactivation. Neuron 7:755-762.

Spitzer NC, Gu X, Olson E (1994) Action potentials, calcium transients, and the control of differentiation of excitable cells. Curr Opin Neurobiol 4:70-77.

Spruston N, Jaffe DB, Williams SH, Johnston D (1993) Voltage- and space-clamp errors associated with the measurement of electrotonically remote synaptic events. J Neurophysiol 70:781-802.

Stefani A, Spadoni F, Bernardi G (1998) Group III metabotropic glutamate receptor agonists modulate high-voltage activated $\mathrm{Ca}^{2+}$ currents in pyramidal neurons of the adult rat. Exp Brain Res 119:237-244.

Swandulla D, Carbone E, Lux HD (1991) Do calcium channel classifications account for neuronal calcium channel diversity. Trends Neurosci $14: 46-51$

Taylor P, Insel PA (1990) Molecular basis of pharmacologic selectivity. In: Principles of drug action (Pratt WB, Taylor P, eds), pp 1-102. New York: Churchill Livingstone.

Thibault O, Landfield PW (1996) Increase in single L-type calcium channels in hippocampal neurons during aging. Science 272:1017-1020.

Thibault O, Porter NM, Landfield PW (1993) Low $\mathrm{Ba}^{2+}$ and $\mathrm{Ca}^{2+}$ induce a sustained high probability of repolarization openings of L-type $\mathrm{Ca}^{2+}$ channels in hippocampal neurons: physiological implications. Proc Natl Acad Sci USA 90:11792-11796.

Thibault O, Porter NM, Mazzanti-Rose ML, Campbell LW, Blalock EM, Landfield PW (1995) Dual patch pipette recordings in hippocampal neurons: evidence that long $\mathrm{Ca}^{2+}$ tail currents reflect $\mathrm{Ca}^{2+}$ channel activity at resting potential. Soc Neurosci Abstr 619:13.

Thibault O, Porter NM, Hadley RW, Landfield PW (1997) Confocal imaging of $\mathrm{Ca}^{2+}$ transients in hippocampal neurons during excitotoxic insult: relationship to enhanced vulnerability of older cultures. Soc Neurosci Abstr 23:1711.

Thibault O, Porter NM, Chen KC, Blalock E, Kaminker KP, Clodfelter G, Brewer L, Landfield PW (1998) Calcium dysregulation in neuronal aging and Alzheimer's disease: history and new directions. Cell Calcium 24:417-433.

Tsien RW, Lipscombe D, Madison DV, Bley KR, Fox AP (1988) Multiple types of neuronal calcium channels and their selective modulation. Trends Neurosci 11:431-438.

Turrigiano G, Abbott LF, Marder E (1994) Activity-dependent changes in the intrinsic properties of cultured neurons. Science 254:974-977.

Turrigiano G, LeMasson G, Marder E (1995) Selective regulation of current densities underlies spontaneous changes in the activity of cultured neurons. J Neurosci 15:3640-3652.

Tymianski M, Wallace MC, Spigelman I, Uno M, Carlen PM, Tator CH, Charlton MP (1993) Cell-permeant $\mathrm{Ca}^{2+}$ chelators reduce early excitotoxic and ischemic neuronal injury in vitro and in vivo. Neuron 11:221-235.

Ujihara H, Albuquerque EX (1992) Ontogeny of $N$-methyl-D-aspartateinduced current in cultured hippocampal neurons. J Pharmacol Exp Ther 263:859-867.

Ulrich D, Quadroni R, Lüscher H-R (1994) Electrotonic structure of 
motoneurons in spinal cord cultures: a comparison of compartmental and equivalent cylinder models. J. Neurophysiol 72:861-871.

Verkhratsky A, Toescu EC (1998) Calcium and neuronal ageing. Trends Neurosci 21:2-7.

Wang HY, Pisano MR, Friedman E (1992) Age-related alteration in G protein function in rat cortex. In: Aging and cellular defence mechanisms, Annals of the New York Academy of Sciences, Vol 663 (Franceschi C, Crepaldi G, Cristofalo VJ, Vijg J, eds), pp 426-428. New York: New York Academy of Sciences.

Weiss JH, Hartley DM, Koh J, Choi DW (1990) The calcium channel blocker nifedipine attenuates slow excitatory amino acid toxicity. Science 247:1474-1477.

Wheeler DB, Randall A, Tsien RW (1994) Roles of N-type and Q-type $\mathrm{Ca}^{2+}$ channels in supporting hippocampal synaptic transmission. Science 264:107-111.

Wickman KD, Clapham DE (1995) G-protein regulation of ion channels. Curr Opin Neurobiol 5:278-285.

Williams ME, Feldman DH, McCue AF, Brenner R, Veleçelebi G, Ellis SB, Harpold MM (1992) Structure and functional expression of $\alpha_{1}, \alpha_{2}$, and $\beta$ subunits of a novel human neuronal calcium channel subtype. Neuron 8:71-84.

Wu L-G, Saggau P (1994) Pharmacologic identification of two types of presynaptic voltage-dependent calcium channels at CA3-CA1 synapses of the hippocampus. J Neurosci 14:5613-5622.

Wu L-G, Borst JG, Sakmann B (1998) R-type $\mathrm{Ca}^{2+}$ currents evoke transmitter release at a rat central synapse. Proc Natl Acad Sci USA 95:4720-4725.

Xia Y, Ragen RE, Seah EEC, Michaelis ML, Michaelis EK (1995) Developmental expression of $N$-methyl-D-aspartate (NMDA)-induced neurotoxicity, NMDA receptor function, and the NMDAR1 and glutamate binding protein subunits in cerebellar granule cells in primary cultures. Neurochem Res 20:617-629.

Yang J, Thio LL, Clifford DB, Zorumski CF (1993) Electrophysiologic properties of identified postnatal rat hippocampal pyramidal neurons in culture. Dev Brain Res 71:19-26.

Zamponi GW, Snutch TP (1998) Modulation of voltage-dependent calcium channels by $\mathrm{G}$ proteins. Curr Opin Neurobiol 8:351-356.

Zhang J-F, Randall AD, Ellinor PT, Horne WA, Sather WA, Tanabe T, Schwartz TL, Tsien RW (1993) Distinctive pharmacology and kinetics of cloned neuronal $\mathrm{Ca}^{2+}$ channels and their possible counterparts in mammalian CNS neurons. Neuropharmacology 32:1075-1088.

Zhang J-F, Ellinor PT, Aldrich, RW, Tsien RW (1996) Multiple structural elements in voltage-dependent $\mathrm{Ca}^{2+}$ channels support their inhibition by $\mathrm{G}$ proteins. Neuron 17:991-1003. 